\title{
TERMINATION OF CONTRACTUAL OBLIGATIONS IN THE CIVIL CODE OF UKRAINE
}

TERMINACIÓN DE LAS OBLIGACIONES CONTRACTUALES EN EL CÓDIGO CIVIL DE UCRANIA

\section{Anatoliy V. Kostruba*}

\begin{abstract}
A contract is a means for self-organization and self-regulation of civil and legal relations between parties in the Civil Code of Ukraine. A distinguishing feature of a contractual obligation is the dependence of the beginning of a legal fact in its structure on the lawful will of a party (act) to a legal transaction or objective circumstance of reality (events). The objective of the paper is to study the mechanism of termination of obligations by determining the legal framework for its functioning. The specificity of legal facts of normative-compensating nature was determined by the use of normative and protective functions in the legislation. Civil property and its legal regulation of relations are aimed at achieving the legal result determined by their participants at the stage of the exercise of rights. The study reveals that the compensating effect of the legal termination mechanism is expressed at the stage of legal termination, which involves compensating the inability to correct a defect of a legal fact that hinders the achievement of a goal of legal regulation when exercising the right to the start of an anticipated legal effect according to a legal model of legal subjects accepted by the participants of the civil relations. The author dwells upon one of the forms of termination of contractual obligations, more specifically, on the beginning of cancellation and on the deferred status of a legal transaction.
\end{abstract}

Keywords: Contract, Legal Fact, Termination of Contractual Obligations, Mechanism of Legal Regulation, Conditional Legal Transaction

* Doctor in Law, Professor of the Department of Civil Law, Vasyl Stefanyk Precarpathian National University, Ivano-Frankivsk (Ukraine). anatolii.kostruba@pnu.edu.ua 
Resumen: Un contrato es un medio para la autoorganización y la autorregulación de las relaciones civiles y legales entre las partes en el Código Civil de Ucrania. Una característica distintiva de una obligación contractual es la dependencia del comienzo en la voluntad jurídica de una parte (acto) sobre una transacción legal o circunstancia objetiva de la realidad (eventos). Este documento tiene por objetivo estudiar el mecanismo de terminación de obligaciones mediante la determinación del marco legal para su funcionamiento. Las cuestiones jurídicas compensatorias se determinaron revisando la normativa general y la legislación protectora de las partes. La propiedad privada y su regulación tienen como objetivo lograr el resultado determinado por la voluntad de las partes a la hora en que ejercen sus derechos. El estudio muestra cómo se dan los efectos compensatorios de terminación contractual en la etapa de terminación: esto implica compensar los problemas surgidos por la terminación defectuosa, procurando dejar a salvo los efectos legales que las partes anticiparon en el acuerdo. El autor hace hincapié en una de las formas de terminación de las obligaciones contractuales, más específicamente, en el comienzo de la cancelación y en el estado diferido de una transacción jurídica.

Palabras clave: Contratos, hecho jurídico, terminación de obligaciones contractuales, mecanismos de regulación legal, negocios jurídicos condicionales

Summary. I. Introduction. II. Regulatory action of the mechanism for the right of termination of contractual obligations. III. The reasons for termination of contractual obligations. IV. Characteristics of changes in contractual obligations. $V$. Compensatory action of the mechanism for the termination of rights of contractual obligations. VI. Beginning of the cancellation condition of a legal transaction in the mechanism for termination of contractual obligations. VII. Characteristic features of referral and annulment. VIII. Conclusions. References.

\section{INTRODUCTION}

A civil contract is the main instrument for the organization of market relations, and contractual regulation is the traditional means of regulation of relations in the fields of private and public law (Parkhomenko, 1998, p. 6; Shevchenko, 2005, p. 23). It should be added that the contract in the civil law of Ukraine is a means for self-organization and self-regulation of the civil and legal relations. 
A legal fact is a specific life circumstance (condition, situation), due to which the legal proposition relates the beginning, change or termination of the legal relations. The uniqueness of such a legal fact as the contract, can be explained by the fact that on the one hand, it is capable of causing the consequences in the beginning, change or termination of the civil legal relations or subjective civil rights, legal obligations, and on the other hand, under the civil contract, both objective and subjective grounds for the movement of proprietary and binding legal relations are fixed, the occurrence of which involves the beginning, change or termination of rights, obligations, or even new civil legal relations between the parties, to the contract. The terms of civil contract establish individual mechanisms for termination of rights in civil relations and legal models of right-terminating legal facts.

The theoretical issues of the contractual regulation of private legal relations are the subject of numerous scientific researches of such scientists as Kuznetsova (2013), Hryniak (2013), Obolonkova (2010), Fedorchenko (2017), and others. However, frequently, the scientists left behind the theoretical and practical problems of the formation and functioning of the mechanism for termination of contractual obligation in the context of the theory of legal facts, which examines the grounds for such termination as individual legal facts and their legal compositions.

The objective of the paper is to study the mechanism for termination of contractual obligations through the determination of the legal structures for its functioning. By means of regulatory and protective functions in the law, it is planned to identify the special features of regulatory and compensatory legal facts.

\section{REGULATORY ACTION OF THE MECHANISM FOR THE RIGHT OF TERMINATION OF CONTRACTUAL OBLIGATIONS}

The characteristic feature of contractual obligation is the dependence of the beginning of the legal fact in its structure on the lawful will of the party (action) of the legal transaction or the objective circumstances of reality (event), the existence of which is foreseen by the legal model of a particular legal fact in the contract, which, when corresponding to the actual circumstances established by such a model, may lead to the reasonable expectations of the parties regarding the legal result and, accordingly, the termination of such an obligation. By means of such legal facts, the operation of the regulatory function of the law is ensured, the content of 
which implements the rights and interests of parties to the contractual obligation, established by the terms of the relevant contract bona fides.

In the theory of the civil law of Ukraine, such legal constructions have been called regulatory right-terminating legal facts. Among the most common, they include alienation. Alienation should be understood as the legal mechanism established by the contract for the transformation of the property right to assets in accordance with its legal regime, which is accompanied by the beginning of the actual consequences of such transformation, resulting in the termination of contractual obligations.

The regulatory effect of alienation as a right-terminating legal fact in contractual obligations, is in the achievement of the purpose of legal regulation established by the parties of the contract. Thus, as a result of alienation, a certain owner exercises their property right through the expression of their, as a result of which the parties of the contractual obligations receive mutual satisfaction.

As well as that, the reason for the termination of a contractual obligation is its proper fulfillment. It involves the observance of the following five established requirements, which are simultaneously the conditions of the beginning of the given right-terminating legal fact: 1) proper object of fulfillment ${ }^{1}$; 2) proper subject of fulfillment ${ }^{2} ; 3$ ) proper date of fulfillment ${ }^{3}$; 4) proper place of obligation fulfillment $\left.{ }^{4} ; 5\right)$ proper manner of fulfillment ${ }^{5}$.

The termination of a contractual obligation by fulfillment involves the exercise of subjective civil rights by its parties and the fulfillment of the counter-legal obligations, which express the object of the obligation. In this way, the purpose of the legal regulation established in the contract is achieved, which implies the satisfaction of common interests of the participants of civil and legal relations. That is, the proper fulfillment is the legal composition with the differential accumulation of its elements, the formation of which inevitably leads to the termination of contractual obligations.

When considering the elements of proper fulfillment, it is impossible to overlook the fact that in cases established by the contract, a third person may be its proper subject; that is, in certain cases, stipulated by the contract, a third person may participate.

${ }^{1}$ Civil Code of Ukraine (2003), Art. 610, 620, 622.

${ }^{2}$ Civil Code of Ukraine (2003), Art. 527, 528.

${ }^{3}$ Civil Code of Ukraine (2003), Art. 530, 531.

${ }^{4}$ Civil Code of Ukraine (2003), Art. 532.

${ }^{5}$ Civil Code of Ukraine (2003), Art. 529, 533. 
The legal status "outside the framework of the contract" does not affect the efficiency of the mechanism for termination of a contractual obligation by proper fulfillment.

It is worth noting that the place (location) of a property or goods plays a certain role in the fulfillment of obligations. The proper places for fulfillment of contractual obligations are as follows ${ }^{6}$ : a) for the obligations on transfer of real estate, at the place of this property's location; b) for the obligations on transfer of goods (property) arising from the contract of carriage, at the place of delivery of the goods (property) to the carrier; c) for the obligations on transfer of goods (property) arising on the basis of other transactions, at the place of the manufacture or storage of the goods (property), if this place was known to the creditor as of the moment of creation of the obligation; d) for monetary obligations, at the place of residence of the creditor, and if the creditor is a legal entity, at its location as of the moment of creation of the obligation. If the creditor changes a place of residence (location) at the moment of creation of the obligation and informs the debtor about it, the obligation is fulfilled at the new place of residence (location) of the creditor, with the assignment of all the losses related to the change of the place of fulfillment to the creditor; and for other obligations, at the place of residence (location) of the debtor (Civil Code of Ukraine, 2003). (The paragraph was rephrased for clarity).

\section{THE REASONS FOR TERMINATION OF CONTRACTUAL OBLIGATIONS}

The reason for termination of a contractual obligation is also the transfer of payoff. The transfer of payoff is made by the conclusion of a legal transaction between the creditor and the debtor, whose purpose is to terminate the principal obligation. Such a legal transaction shall confirm the achievement of agreement between the parties regarding the quality and quantity of the object, which is the payoff, the deadline for the transfer of the payoff, the procedure of its transfer, as well as fixing the time of termination of the contractual obligation.

Article 604 of the Civil Code of Ukraine states that obligations may also be terminated by the agreement of parties. The cancellation of a contract is a condition linked to the partial or full termination of the contractual obligation, until the moment of its legal and actual fulfillment. If both parties agree to terminate the obligation, then it can be exercised on

${ }^{6}$ Civil Code of Ukraine (2003), Art. 532. 
the conditions of contract. That is, the cancellation of the contractual obligation by agreement of parties is also the way of its termination. Any agreement for the termination of contractual obligations has evidence of legal transactions with the special feature that they are aimed at the termination of subjective civil rights and legal obligations that arose on the basis of the primary contract. Consequently, such agreements must comply with the general requirements for the lawfulness of legal transactions, foreseen by Article 203 of the Civil Code of Ukraine. Thus, the termination of a contractual obligation by agreement of parties is executed in the form established for the conclusion of such an obligation. It should be noted that the termination of the contract by agreement of the parties entails not only the termination of rights and obligations of its parties, but also a number of other legal consequences.

According to Article 601, a contractual obligation is terminated by the offset of counter uniform claims, the term of fulfillment of which has expired, as well as the claims, for which term of the fulfillment has not been set, however, is determined by the time when the claim is made ${ }^{7}$. Thus, the offset implementation is possible in the presence of the following conditions: a) the uniformity of the civil obligations (the object of both obligations must be of the same kind); b) counter character of claims in the obligation (the creditor of one obligation is simultaneously the debtor under another obligation, and vice versa - the debtor of the first obligation is the creditor of the another one); c) the beginning of the time of fulfillment of the civil obligations; d) the conclusion of the legal transaction on the offset of the counter uniform claims; and, e) the fulfillment of the reconciliation of offsets on the basis of uniform obligations, which are terminated by the offset of the counter uniform claims.

There are currently several approaches as to the moment of the beginning of the indicated right-terminating legal fact. According to the first one, the offset is considered as completed and repays set-off claims at the time of sending a notification of the offset to the other party.

The second approach implies that a civil obligation is considered to be terminated by the offset, from the moment of expiry of the term for the fulfillment of the obligation that came later. This position is argued by the fact that from the moment of the expiry of the termination term of the civil obligation, the payment of penalty and the interest ceases because the obligations are considered to be repaid.

However, the phenomenon of reciprocity of offset will lead to the fact that, before the receipt of application for it — which is, of course, necessary

\footnotetext{
${ }^{7}$ Civil Code of Ukraine (2003), Art. 601.
} 
for the legal validity of the offset - the parties may be regarded as being in default. At the same time, for the period from the beginning of the delay to the termination of the obligation offset, only the party, whose term of obligation fulfillment has come earlier, may be considered in default (Sarbash, 2001, pp. 87-88).

The third option is based on the assumption of the involvement of counter-parties by the offset, from the moment of receipt of the notification by the addressee party. The choice of this approach will necessarily raise the question of the admissibility of recalling the offset (by analogy with recalling the offer) until the receipt of the corresponding notification by the addressee. A civil obligation may also be considered terminated after the expiry of the necessary amount of time for the receipt of the application on the offset by the other party. If this party has reasons to consider it to be carried out in the absence of the necessary condition or in inconsistency with at least one of the necessary conditions, such a person may file to the court for the recognition of the offset as invalid and fulfillment of the requirements of the contract (Mikhno, 2004, p. 53).

Syrotkina (2009, p. 51) specifies that the termination of a civil obligation by offset, unlike other types of unilateral legal transactions, entails the termination of both rights and obligations of the applicant of the offset and its counter-party.

One of the grounds for the termination of a contractual obligation, in accordance with Article 605, is the release of the debtor from their obligations by the creditor (debt forgiveness). Based on the fact that one party - the creditor-has a subjective civil right, the legal obligation is imposed on its counter-party - the debtor. That corresponds to the certain subjective civil right to terminate the contractual obligation, which is carried out in direct and reverse order. The direct order involves the fulfillment of the legal obligation of the creditor, while the reverse one-in the deprivation of the subjective civil right, which corresponds to such an obligation.

Debt forgiveness is characterized by the fact that the creditor relieves the debtor from the fulfillment of their obligations without requiring the counter-performance of the obligations resulting in the termination of the corresponding contractual obligation. This is an unconditional, unilateral legal transaction, the termination of the contractual obligation of which is performed in reverse order.

In accordance with Article 606, a contractual obligation is terminated by the combination of the debtor and the creditor in one person (confusio). Each civil obligation implies the existence of three of its main elements: subject, object and content. Unlike the others, the exclusion of such an element of obligation as the subject terminates its existence. The formula for 
such an exclusion is the combination of the debtor and the creditor in one person.

\section{CHARACTERISTICS OF CHANGES IN CONTRACTUAL OBLIGATIONS}

When the debtor and the creditor are combined in one person, the contractual obligation undergoes certain changes. One person assumes all legal properties of the other in the contractual obligation, therefore terminates the status of participant in the relevant legal relations. Previously, existing legal links between the parties are absorbed by the person that has joined two (or more) participants in such an obligation. As a result, the party and the counter-party are combined: debtor and creditor cease being the same subject of such a contractual obligation.

For instance, citizen A. and citizen $\mathrm{K}$. are the parties of the legal lease relations concerning real estate. The real estate is the property of citizen A., and citizen $\mathrm{K}$. is respectively the lessee. While being in the legal lease relations, the parties conclude the contract of sale, which results in the transfer of a property to the ownership of citizen K. At last, the conclusion of the contract of sale changes the legal lease relations, as a result of which they are terminated.

The terms in the civil law of Ukraine are a significant legal category, which determines not only the regularization of the civil circulation in time, but also ensures the possibility of performance and implementation of their rights by the subjects of the civil relations, inducing the obligated persons to perform their obligations and the possibility of timely protection of the violated rights. The subjects of the civil law exercising their rights are interested in ensuring that their (rights) and obligations are exercised not only properly, but also in a timely manner.

The beginning of the term is such a legal fact that may lead to the termination of a contractual obligation. Its peculiarity is that it is attributed to the events, even regardless of the fact that its course may depend on the will of the participants in the civil legal relations.

In particular, Item 5, Part 1, Article 1141 of the Civil Code of Ukraine states that simple a partnership contract shall be terminated in case of expiry of the simple partnership contract period. In this case, the right-terminating fact is the moment of expiry of the simple partnership contract period. That is, the expiry of the period is a law-terminating legal fact.

The termination of a contractual obligation by the expiry of the period is provided by the foreign civil law of the European countries. For example, 
Article 1737 of the Civil Code of France (2016) regulates that, "Le bail cesse de plein droit à l'expiration du terme fixé, lorsqu'il a été fait par écrit, sans qu'il soit nécessaire de donner congé". A similar legal norm is also contained in Article 2219, which states that the statute of limitation is a means of establishing or repaying the obligation in case of the beginning of a certain term and in the presence of the relevant conditions established by the law. So, the expiry of the contract period as the basis for termination of a contractual obligation is a characteristic of many contracts and determines their legal nature.

At the same time, in the legal literature, there is an opinion that the expiry of the contract period cannot always be identified with the grounds for termination of the obligations (Kossak, 2004, p. 17). The termination of civil obligations is a legal consequence of the validity of legal facts (volitional actions of participants in the civil legal relations) aimed at the termination of the civil rights and obligations of specific subjects. After the beginning of such a legal fact, the civil legal relations between these entities are terminated. This thesis is reflected in Article 764 of Civil Code of Ukraine, which states that when the lessee continues to use the property after the expiry of the contract of lease, then, in the absence of the objections of the lessor within one month, the contract is considered as renewed for the period established by the previous contract.

\section{COMPENSATORY ACTION OF THE MECHANISM FOR THE TERMINATION OF RIGHTS OF CONTRACTUAL OBLIGATIONS}

Traditionally, the achievement of the aim of legal regulation of social relations is ensured by the lawful behavior of the subjects of the relevant legal relations within the limits of the program of legal actions established by them.

At the same time, the situation of a social conflict that arises between the parties of the contractual obligations is not an exception. The conditions of its beginning and its development start the legal consequence, which was not foreseen by the parties of the legal transaction as the aim, the achievement of which is the will of the parties.

The compensatory nature of the indicated right is in the compensation of the defect of the actual or legal side of the legal fact by the beginning of the corresponding consequence adjusted to the new legal model of the behavior of the participants in the civil legal relations.

Thus, Part 1, Article 615 of the Civil Code of Ukraine states that "in case of violation of the obligation by one party, the other party shall have 
the right to refuse, partially or completely, the obligations established by the contract or by the law". In this case, it is advisable to speak about such a right-terminating legal fact of a contractual obligation as its termination on request of one party. The refusal to fulfill the contract is considered as justified only if the fulfillment violates the terms and conditions of the contract or when the contract cannot be fulfilled for other reasons, which do not depend on the will of the parties. The unilateral refusal to fulfill the obligations is considered as a way to protect the violated right, in this regard, the mechanism for the termination of contractual obligations takes a protective form.

When investigating the problem of implementation in the mechanism for the termination of the right of contractual obligations of the protective function of the civil law, it should be noted that the reason for the beginning of a legal fact that terminates such an obligation is the violation of the terms and conditions of the contract by the parties. The form of violation may be causing damage, losses or fulfillment of the obligations at such a slow pace that it makes it impossible to terminate it within the period specified by the contract.

In some cases, the exercise of the right to unilateral refusal from the contract is due to other circumstances that are not related to the violation of the contract. Their beginning may be caused both by the external facts and by such actions that do not have any signs of violation of the right (Obolonkova, 2010, p. 17). The provision of the right to refuse a contractual obligation is always based on the impossibility of achieving the aim in its legal regulation.

Firstly, granting the right to refusal is related to the fiduciary nature of the contractual relations of the parties ${ }^{8}$. Secondly, the right to unilateral refusal is granted to the parties when the contract is concluded without a time limit. In this case, granting the right to unilateral refusal is conditioned by the necessity of providing the parties with the contract, the action of which does not have specific time limits, additional opportunities for its termination (except for reaching agreement by them), in case of the loss by one of the parties of the interest in the further fulfillment of the contract ${ }^{9}$. Third, the right to unilateral refusal, which is not conditioned by any circumstance, is granted to an economically weaker party to the contracta natural person ${ }^{9}$.

The given mechanism for proper termination of a contractual obligation causes legal consequences as a result of the unilateral action of

\footnotetext{
${ }^{8}$ Cfr. Civil Code of Ukraine (2003), Art. 1008, part 1, item 1.

${ }^{9}$ Cfr. Civil Code of Ukraine (2003), Art. 1141, part 1, item 4.
} 
the party of the contract. This breaks legal relations between the participants in the civil legal relations, so obligations are ended at a certain stage of their development. Such a termination of the contractual obligation may occur at any stage of its development.

Part 2 of Article 604 states that a civil obligation shall be terminated by the agreement of the parties on the replacement of the original obligation with a new obligation between the same parties (innovation) ${ }^{10}$. The innovation covers the cases of termination of a contractual obligation by transforming its content. It also adjusts its object. In this case, such an element as the subject of the obligation remains unchanged.

For example, if the customer under the contract of work and labor remained indebted to the counter-party for the performed work, the parties can turn the debt into a loan obligation: the counter-party becomes the lender, while the customer becomes the borrower. In this case, there is a bilateral civil obligation on the grounds that one of two obligations is terminated, and the other-terminated wholly. At the same time, the second one acquires a completely different form of a civil legal obligation of the loan one. In addition, this new civil law obligation has its own independent content, which differs from the others. In addition, this new obligation gains particular features that give it individuality. These peculiarities are expressed in connection to the new obligation with the previous one, and also in the reversal of the object of this preliminary obligation.

A contractual obligation is also terminated by the impossibility of its fulfillment in connection to the circumstance for which neither party is responsible ${ }^{11}$. Unfortunately, the Civil Code of Ukraine does not establish the criterion for the impossibility to fulfill an obligation. Whether it is the circumstance that makes it impossible to fulfill the obligation or the circumstance that has changed the conditions, due to which the parties (party) cannot fulfill the obligation objectively, regardless of all the other circumstances. In addition, the law does not reveal the concept itself of the impossibility to fulfill an obligation.

The impossibility to fulfill a civil obligation leads to its termination in case when the condition of impossibility arose after the implementation of a legal transaction. It is inappropriate to speak about the termination of the civil obligation on the indicated ground if the impossibility is generated by the guilty behavior of one of the parties.

With the death of the natural person (or the liquidation of the legal entity), its legal capacities are also terminated alongside with the proprietary

\footnotetext{
${ }^{10}$ Cfr. Civil Code of Ukraine (2003), Art. 604, part 2.

${ }^{11}$ Civil Code of Ukraine (2003), Art. 607.
} 
rights and the binding rights, as well as participation in the contractual obligations.

In accordance with the general rule established by the Civil Code of Ukraine (2003), a civil obligation must be fulfilled by the debtor personally, unless otherwise provided for by the law or the contract. The fact of the death of the natural person (the liquidation of the legal entity) objectively affects the stated purpose of legal regulation of the relevant civil legal relations.

\section{BEGINNING OF THE CANCELLATION CONDITION OF A LEGAL TRANSACTION IN THE MECHANISM FOR TERMINATION OF CONTRACTUAL OBLIGATIONS}

In most cases, the "life" of a legal transaction is associated with the unconditional factors to achieve its purpose. At the same time, the parties of a legal transaction have the opportunity to determine the existence of the circumstances (their presence or absence) that may affect the dynamics of a contractual obligation between them in advance. It gives the right to existence of such a legal phenomenon as conditional legal transactions. The aforesaid is aimed to minimize the possible risks associated with the uncertainty in the development of the events that determine its implementation (Fedorchenko \& Kalaur, 2017, p. 36).

In legal literature, in the division of all the legal transactions into conditional and unconditional, the legal transactions with the cancellation and delayed conditions belong to the first category. According to the thought settled in the civil law, a legal transaction is conditional, in which the beginning, change or termination of the civil rights and obligations depends on the beginning or non-beginning of a particular circumstance. Such a circumstance, that is, should not be the essential condition of the legal transaction, it is a casual element.

There are two traditional types of terms of legal transaction: conditions with delay or suspension (from lat. suspensus - suspended, delayed), and cancellation or resolution (from lat. resolutivus - final) circumstances.

Thus, according to the first and second paragraphs of Article 212 of the Civil Code of Ukraine, persons implementing a legal transaction have the right to determine the beginning or change of rights and obligations by the circumstance, concerning which it is unknown whether it comes or not (delayed circumstance) ${ }^{12}$. The persons implementing a legal transaction have the right to stipulate the termination of the subjective civil rights and

\footnotetext{
${ }^{12}$ Civil Code of Ukraine (2003), Art. 212.
} 
legal obligations by the circumstance, which is unknown whether it comes or not (cancellation circumstance).

As it is seen from the above-mentioned provisions of the Civil Code of Ukraine, the legislator delimits the delayed and cancellation consequences, which results in the legal transactions, where such circumstances are stipulated. In the projection of legal facts, the delayed circumstance has the character of a right-establishing or right-changing act or event, whereas the beginning of the cancellation condition is defined by regulations as a right-terminating legal fact of contractual obligations.

At the same time, it is notable that such a division is quite arbitrary in view of the complex and relative nature of legal facts. Thus, in the legal transactions aimed at the transfer of things into ownership, use or possession of a person, the beginning of a delayed and cancellation condition has the character of a right-terminating legal fact through its combined legal consequences.

However, the cancellation condition in its nature should always result in the form of termination of rights, obligations, legal relations, or powers in the legal relations. The nature of a delayed condition is that it is not a legal transaction, but its consequences come after a certain period of time, i.e. they are delayed.

The cancellation and delayed conditions of a legal transaction are characterized by the following properties: a) they may be certain legal facts that do not exist at the time of the legal transaction; b) the beginning of such legal facts should have a possible nature, that is, the party (parties) of the transaction should be unaware of whether a certain circumstance occurs in the future; c) the circumstance defined in the legal transaction as a condition, must be real and cannot contradict the acts of the civil legislation of Ukraine, the interests of the state and society, and its moral norms.

The cancellation condition in a legal transaction by its nature is a circumstance reflected in the legal relations, mainly due to the will of the parties. This means that the parties carry out independently the initial fixation of the relevant legal model of the cancellation condition at the stage of its conclusion.

It should be noted that the legal regulation of implementation and fulfillment of the legal transactions with delayed and cancellation circumstances, in principle, is limited to the general provisions of Article 212 of the Civil Code of Ukraine, which, in essence, determines the peculiarities of fulfillment of these legal transactions and actions of the relevant mechanism for the right establishment, right change and right termination of contractual obligations ${ }^{12}$. At the same time, the structures above are mentioned in other provisions of the Civil Code of Ukraine. In 
particular, with regard to the delayed condition of the legal transaction, its use is characteristic of the deed of a gift with the obligation to hand over the gift in the future and a lease contract with the ransom.

Thus, the deed of a gift may set the grantor an obligation to hand over a gift to the grantee in the future after a certain term (within a certain period) or in case of the beginning of the delayed condition ${ }^{13}$. With regard to the lease of housing with the ransom, the lease contract with ransom is a document indicating the transfer of the property right to the real estate from the enterprise - the lessor to the lessee with delayed circumstances determined by the law ${ }^{14}$. In its turn, the cancellation condition of the legal transaction is mentioned only in one article of the Civil Code of Ukraine, in addition to Article $212^{12}$ - this is Article 1142, in accordance with the second part of which, the party of a simple partnership contract concluded for a specified period or the contract, in which the achievement of the purpose is defined as a cancellation condition, has the right to demand the termination of the contract in relations with other participants due to a valid reason, with the reimbursement to the other participants of the real damage caused by the termination of the contract ${ }^{15}$.

Notably, in view of the definition of the delayed and cancellation conditions in Article 212, they can also be applied to unilateral legal transactions ${ }^{12}$. Again, the provision of Article 723 of the Civil Code of Ukraine serves in favor of this circumstance, which provides for the possibility of the existence of the variance of the deed of a gift with the obligation to hand over the gift in the future. Thus, in accordance with part two of the aforementioned article, in case of the expiry of the period (term) or the delayed circumstance established by the deed of a gift with the obligation to deliver the gift in the future, the grantee has the right to demand from the grantor to transfer the gift or to reimburse its value ${ }^{16}$.

For the cancellation condition, the beginning of which is a rightterminating legal fact, it is characteristic that it cannot be an essential condition of the legal transaction. The explanation of this circumstance lies in the very nature of the legal transaction as a conscious volitional action aimed at the beginning, change or termination of civil rights and/or obligations. Consequently, the nature of the essential condition of the legal transaction actually impedes the implementation of the cancellation condition by the parties. The cancellation condition at the time of the

\footnotetext{
${ }^{13}$ Civil Code of Ukraine (2003), Art. 723, part 1.

${ }^{14}$ Civil Code of Ukraine (2003), Art. 810, part 7.

${ }^{15}$ Civil Code of Ukraine (2003), Art. 1142, part 2.

${ }^{16}$ Civil Code of Ukraine (2003), Art. 723, part 2.
} 
conclusion of the legal transaction exists only in ideal form. That is why in fact, in real life, the relevant circumstance should arise only in the future. Herewith, it is not known for sure whether it comes or not.

Consequently, the cancellation condition is a certain circumstance of reality, with the beginning of which the rights are terminated. However, at the same time, this circumstance may not depend on the will of the parties of the legal transaction - in this regard, it is not the circumstance that should be considered as the cancellation condition, but the fact of its beginning. It is precisely the fact of the beginning of one or another condition, implementation of action, arising of a certain phenomenon that is the "final point" in the process of formation, existence or termination of such a phenomenon. The termination of the right in legal transactions with the cancellation condition is a legal consequence of the reason in the form of the beginning of the cancellation condition.

\section{CHARACTERISTIC FEATURES OF REFERRAL AND ANNULMENT}

A characteristic feature of the referral and cancellation circumstances, the beginning of which is a legal fact, is that they are of an "objectified" nature and their beginning must, in most cases, occur without the parties' participation in the legal transaction, or with their participation, but without creating the obstacle for the counter-party in the contractual obligation. Although, the mechanism for the termination of rights of contractual obligations can act both according to the objective and subjective scenario.

In general, it can be stated that the beginning of the cancellation condition of a legal transaction is a right-terminating legal fact with a delayed mechanism for action. The very nature of such a legal transaction determines the circumstance that there is a certain period of time between the moment of its conclusion and the beginning of consequences (Hryniak, 2013, p. 344).

Notably, the cancellation condition as an element of the contract, as well as the basis for termination of contractual obligations, may take place only within the limits of the existing legal relations and only within the limits of the current legal transaction. In other words, a cancellation condition may be reflected as its element, when such a legal transaction is actually concluded. At the same time, the parties cannot agree on the cancellation condition of the legal transaction, if it has not yet happened because such an agreement will not have sufficient validity in order to be reflected in the future legal transaction. 
The cancellation condition of a legal transaction acts on the principle of the certain fiction of a legal fact. Based on the fact that the cancellation condition is a circumstance of reality, which, to a small extent, depends on the parties to the legal transaction, the corresponding rights or legal relations are terminated with its beginning, regardless of the fact of transfer of things.

In addition, due to its nature, the cancellation condition of a legal transaction may be not directly related to the specific legal relations. Only the parties to the legal transaction interpret such circumstances differently in its conditions, give it the role of a legal fact that has certain legal consequences and, in some cases, is not physically reflected.

It is possible to attribute to the peculiarities of the cancellation condition, the beginning of which is a right-terminating legal fact of contractual obligation of a legal transaction, the fact that, on the one hand, such circumstance, or rather its legal model, is considered an element of the legal transaction. After it has been consolidated under the terms of the legal transaction, it is necessary and sufficient for the operation of such a contract, although, it does not have the feature of an essential condition. On the other hand, the cancellation condition is the result of the creative approach of the parties of the legal transaction towards the formation of its terms and therefore is considered as a circumstance that terminates legal relations, due to the fact that it is reflected in the legal transaction by the will of the parties.

It should be noted that the cause-and-effect relation between the cancellation condition of the legal transaction and the legal consequence of its beginning in the mechanism for the termination of rights of contractual obligations is characterized by a pronounced formalized structure. Thus, regardless of what is intended as the cancellation condition, it results in the termination of rights and obligations of the parties of the legal transaction. It means that civil and legal relations are terminated with the beginning of the cancellation condition itself of the legal transaction, regardless of whether it is related to the transfer of things, the performance of certain works or the provision of services.

Nevertheless, the order of occurrence of legal consequences of the cancellation condition may also be specified. In fact, it is possible to distinguish two orders of beginning of consequences of the corresponding condition in the legal transaction - objective and subjective.

Objective termination of a right is characterized by the fact that a contractual obligation is terminated automatically from the moment of the beginning of the relevant condition.

For example, the parties of a legal transaction may foresee that the rights and obligations of the parties are terminated from the moment of the death of one of the lessor's parents. Under such circumstances, the 
contractual obligation shall be deemed to be terminated from the moment of the biological death of the relevant person, regardless of all the other circumstances.

As for the subjective termination of rights, it is characterized by the fact that parties envisage the moment of the cancellation condition not when the actual corresponding condition occurs, but the moment when the person learns about the beginning of the relevant circumstances.

Such an arrangement is based on the principle of good faith and is characterized by the fact that relevant consequences come from the moment when the party of contract learned or could learn about the beginning of such circumstances. In the example showing the death of a parent of the lessor, the subjective termination of right was characterized by the moment when the lessee learned or could learn about the beginning of the cancellation condition, for example, when the lessee informed them about the beginning of such a circumstance adding the copies of relevant documents.

However, if looking at the given situation in terms of objective termination, then the legal transaction, in fact, is terminated from the moment of the relevant circumstance, regardless of whether other members of the civil and legal relations learned about the beginning of such a circumstance. At the same time, in the course of the legal transaction itself, in order to avoid misunderstanding and abuse, the parties to the legal transaction foresee the order of fixing and the proof of the existence of the cancellation condition.

Both objective and subjective termination of rights lead to one consequence, but give rise to various risks. In the case of the subjective termination of a right, the relevant party receives a required amount of information regarding its condition. From the moment it is received, the party has some time to take the necessary actions to terminate the contractual obligation completely and not to cause negative consequences (Kuznietsova, 2013, p. 57).

In the case of objective termination, the relative party may not be aware of the beginning of the condition. During the time between the relevant condition has come and the person has learned about its beginning, the party uses the benefits without a sufficient legal basis, and therefore its counter-party can apply negative consequences to such a person in the form of penal sanctions (Bondar, 2018, p. 22; Fedchyshyn \& Ignatenko, 2018, p. 27).

Notably, the cancellation condition of a legal transaction is the construction that fits into the basic principles of functioning of the mechanism for termination of right of contractual obligations and is consistent with the procedure for the fulfillment and the termination of legal 
transactions. In particular, in our opinion, the cancellation condition may be reflected in terms of the legal transaction as the basis not only for the termination of the contractual obligation as a whole, but also for the termination of individual rights and obligations of participants of the corresponding legal relations.

This means, firstly, that the beginning of the cancellation condition, as well as any other legal fact in the mechanism for the termination of contractual obligations, may have different manifestations at different levels of existence or the termination of legal phenomena.

The aforesaid indicates the possibility of its effect on individual rights, powers or obligations of parties to the legal transaction, and on the legal relations in general. That is, by virtue of terms of the contract and the nature of a particular model of the cancellation circumstance, the relevant contractual obligation is terminated completely.

Secondly, the cancellation condition of a legal transaction may trigger a direct or reverse mechanism for the termination of contractual obligations. That is, it may terminate legal obligations in connection to the termination of a subjective civil right, or vice versa, may terminate subjective civil rights in connection to the termination of the legal obligation of the party to the legal transaction.

Thirdly, the cancellation condition of a legal transaction may be applied to the whole transaction or to a particular part thereof. As a consequence, the cancellation condition of the legal transaction may change the nature of legal relations, turn a bilateral legal transaction to a unilateral one or a singular legal transaction to a mixed one, etc.

\section{CONCLUSIONS}

1. In the legal regulation of the civil property relations, the contract ensures the interests of the participants of the civil and legal relations, while retaining the ability to be flexible within the mechanisms for balancing the interests of specific subjects of the civil and legal relations, society, and state. Legal regulation of the civil property relations is aimed at achieving the legal result determined by their participants at the stage of the exercise of the right. At this stage, right-terminating legal facts, with the help of the appropriate mechanism for the termination of right, ensure the beginning of the consequence agreed by the parties in the form of termination of right.

2. The achievement of the purpose of legal regulation of the civil property relations at the stage of the exercise of the right is ensured by the regulatory action of the mechanism for the termination of right. Such right- 
terminating legal facts, in binding legal relations, are as follows: alienation, the merge of the debtor and the creditor into one person, the termination of obligations by the agreement of parties, proper fulfillment of the civil obligations, the offset of the counter uniform claims, transfer of payoff, debt forgiveness, the expiration of terms and conditions of the contract, etc.

3 . The emergence of a defect of a legal fact at the stage of the exercise of the right leads to the impossibility for their participants to achieve the purpose of the legal regulation of the civil property relations. The nature of the defect of the legal facts at this stage changes the model of the legal regulation of civil and legal relations. There is a replacement of the stage of the exercise of right by the stage of the termination of right of the civil property relations.

4. At the stage of the termination of right, the compensatory effect of the mechanism for the termination of right is manifested. The effect is in the compensation of the inability to correct a defect of a legal fact that interferes with the achievement of the purpose of the legal regulation at the stage of the exercise of the right by the beginning of the expected effect corresponding to the legal model of the subjects, of the law adopted by the participants of the civil and legal relations.

Such compensatory right-terminating legal facts include the death of the natural person, the termination of obligation on request of one party, innovation, the impossibility to fulfill the civil obligation, etc. 


\section{REFERENCES}

Bondar, O. (2018). Public administration in the field of land use and protection and state land policy in Ukraine: Problems of correlation. Baltic Journal of Economic Studies, 4(3), pp. 22-27.

Civil Code of Ukraine (2003). Retrieved from http://cislegislation.com/document.fwx?rgn=8896 (18-IX-2017).

Code Civil of France. (2016). Retrieved from https://www.legifrance.gouv.fr/affichCode.do?cidTexte=LEGITEXT00000607 0721\&dateTexte=20170620 (18-IX-2017).

Fedchyshyn, D., Ignatenko, I. (2018). Protection of land ownership of foreigners in Ukraine. Juridical Tribune-Tribuna Jurídica, 8, pp. 27-38.

Fedorchenko, N., \& Kalaur, I. (2017). Legal Regulation of Obligations on Service Delivery in the Context of the Development of Ukraine's Economy. Journal Transition Studies Review, 24(1), pp. 34-39.

Hryniak, A. B. (2013). Contractual Obligations to Perform Work in the Civil Law of Ukraine. Kyiv: Institute of private law and entrepreneurship of the National Academy of Legal Sciences of Ukraine.

Kossak, V. M. (2004). Problems of Termination of Obligations Under the New Civil Code of Ukraine. Actual Problems of State and Law: Collection of Research Papers, 23 , pp. 17 y ss.

Kuznietsova, N. S. (2013). Development of Civil Society and Modern Private Law in Ukraine. Private Law, 1, pp. 51-64.

Mikhno, O. I. (2004). Civil Aspects of Offset as a Way to Terminate Contract. Problems of Legality: Republican Interdepartmental Scientific Reports, 67, pp. 53 y ss.

Obolonkova, E. (2010). Unilateral Refusal from Fulfillment of Obligation: classification issue. Economy and Law, 2, pp. 17 y ss.

Parkhomenko N. M. (1998). The Contract in System of Law of Ukraine. Kiev: V.M. Koretsky Institute of State and Law of National Academy of Sciences of Ukraine.

Sarbash, S. (2001). Termination of Obligations by Offset Arbitrary Practice. Economy and Law, 10, pp. 87-88.

Shevchenko, L. I. (2005). On Concept, Essence, and Meaning of Contractual Regulation of Property Relations in Market Economy. State and Law, 10, p. 43.

Syrotkina, A. (2009). Termination of Obligations. Economy and Law, 4, p. 51. 